\title{
Muslim Consumers' Purchase Behavior Towards Shariah Compliant Hotels in Malaysia
}

\author{
A. Haque \\ International Islamic University Malaysia \\ N. A. Chowdhury \\ International Islamic University Malaysia \\ F. Yasmin \\ Lincoln University College, Malaysia
}

\section{A. K. Tarofder}

Management and Science University Malaysia

\begin{abstract}
As the number of Muslim tourists drastically increased, the concept of Shariah Compliant Hotel (SCH) has become a vital concern particularly in Islamic tourism. Shariah compliance is one of the primary aspects that influence Muslim consumers' choice of accommodation while travelling. For such reason, the present study has been developed to examine the factors that affect Muslim consumers purchase behavior towards Shariah compliant hotels. Henceforth, a conceptual framework has been constructed based on past literature. The primary data were collected from Muslim travelers specifically in Kuala Lumpur, Malaysia using a self-administered questionnaire. Statistical Package for Social Sciences (SPSS) and Structural Equation Modeling (SEM) were employed to analyze data. Based on the results the aspects of halal image, followed by halal awareness along with religiosity have been found to have profound effects on Muslim consumers purchase intention towards Shariah compliant hotels. Further, purchase intention has a significant effect on purchase behavior towards Shariah compliant hotels. The outcomes derived from this research will be of immense importance for destination marketers as
\end{abstract}

\section{Corresponding Author:}

Ahasanul Haque, Department of Business Administration, International Islamic University Malaysia, Box No 10 50728 Kuala Lumpur.E-mail: ahasanul@iium.edu.my 
well as hoteliers for crafting effective strategies in terms of meeting the needs of Muslim consumers. At the same time, the study would also facilitate future researchers to undertake more studies in Islamic tourism particularly, Shariah compliant hotels.

\section{Keywords}

Shariah compliant hotels, purchase behavior

\section{Introduction}

An understanding of the factors that shape Muslim consumers' behavior has become a topic of much interest among researchers and academics particularly in Islamic marketing. As the consumption habits of Muslim consumers are largely shaped by their belief and adherence to the principles of Islam, significant initiative has been taken by marketers in various regions of the globe for tailoring their goods along with services to fulfill the unique desires and demands of the Muslim population. The primary reason that has given rise to such an occurrence is the fact that the Muslim market has been recognized as one of the leading emerging markets which is relatively untapped. As a result, Muslim consumer market is considered to be a viable segment which has the potential of being further served by marketers.

The needs and wants of the Muslim consumer market is, to a large extent, molded by their firm believes in the Islam religion and its values (Henderson, 2003). Muslims are required to follow the guidelines of halal and haram in all facets of their everyday lives even during the time of travelling. In terms of Muslim consumers, adherence to religious principles is utmost important when it comes to the aspect of accommodation while travelling. Henceforth, compliance to Islamic values and principles are integral for the hotel industry for satisfying the demands of Muslim travelers. For such reasons, Shariah compliant hotels have emerged as a crucial aspect in Islamic tourism. From a general perspective, Shariah compliant hotels are referred to hotels that are established specifically for meeting the requirements of Muslim consumers through offering services that reflect Islamic principles.

In recent time, competition within the tourism industry has accelerated at a rapid pace and with the growing number of Muslim travelers, Shariah compliant accommodation has turned into an issue of much importance. When travelling to foreign destinations, Muslim consumers face various obstacles in searching hotels established that adhere to the guidelines of the Shariah. The 
unavailability of hotels that are in line with their religious values creates a dilemma for Muslim travelers (Zamani-Farahani and Henderson, 2010). The inability of destinations hosts to deliver accommodation facilities that congruent with Islamic principles greatly discourages Muslim travelers to visit the respective destinations (Battour and Battor; 2010). Therefore, to attract and retain Muslim consumers' accommodation providers and destination marketers should meet their religious needs through providing services which are Shariah compliant. Despite this, an extent review of prior literature demonstrated the presence of an apparent lack of studies on Muslim consumers purchase behavior towards Shariah compliant hotels (Idris and Razali, 2016; Yunus et al., 2014). To bridge this gap, the present study seeks to identify the factors that affect Muslim consumers purchase behavior towards Shariah compliant hotels. The study develops few specific objectives which are;

- To determine the effect of halal image on purchase intention towards Shariah compliant hotels

- To investigate the effect of halal awareness on purchase intention towards Shariah compliant hotels.

- To examine the effect of religiosity on purchase intention towards Shariah compliant hotels.

- To examine the effect of purchase intention on purchase behavior towards Shariah compliant hotels.

\section{Literature Review}

\section{Hotels/Shariah Compliant Hotels}

The tourism and hospitality industry have experienced immense transformation and emerged as one of the largest as well as fastest growing industries globally (Kandampully and Suhartanto, 2000). Hotels are an integral part of the tourism industry which significantly contribute to the overall tourism experience through the delivery of standardized facilities and services (Xuan, 2017). Hotels are considered to be the primary type of accommodation providers, occupying the biggest share both in terms of the amount and type in the tourist accommodation industry system (Rishipal, 2014). The use of hotel facilities such as rooms, restaurants and wellness services are no longer considered a luxury rather they have become an integral component of consumers' lifestyle (Kandampully and Suhartanto, 2000). Over the past two decades, the demand and supply for hospitality services has been increased drastically and resulted in intense competition (Kandampully and Suhartanto, 2000). In order to survive in the competitive environment, it has become imperative for hotels to adequately satisfy the needs and wants of the diversified groups of consumers which led to 
the development of a newer concept of hotels widely known as Shariah compliant hotels (Salleh et al., 2014). Shariah compliant hotels are described as hotels that offer services that are in line with the teachings of Islam and Islamic values (Saad et al., 2016). Henceforth, Shariah compliant hotels comprise a wide range of attributes such as the prohibition of alcohol, night clubs and bars, availability of halal food, prayers room, Quran and prayer mats in each room, separate facilities for men and women, Shariah compliant funding and management (Samori \& Rahman, 2013; Henderson, 2010; Rosenberg and Choufany, 2009). Shariah compliant hotels are a vital component of Islamic tourism and hospitality industry developed particularly to satisfy the special needs of Muslim consumers (Idris and Razali, 2016). These needs largely depend on the rules and regulations prescribed in Islam (Saad et al., 2016). Hotels can attract and increase the number of Muslim tourists through the fulfilment of such needs (Battour et al., 2011).

\section{Halal Image and Purchase Intention}

The term halal symbolizes permissibility with respect to Islamic guidelines (Deuraseh, 2009). In marketing, the aspect of halal is used to understand the permissibility for a product/service on the basis of the teachings of the Holy Quran (Suki and Salleh, 2016; Lada et al., 2009). Statistics have revealed that the concept of halal is largely considered by Muslim consumers as it has been found that $70 \%$ of Muslim population at the global level follow halal standard (Lada et al., 2009). From an Islamic standpoint, halal image represents the perceptions of Muslim consumers on brand characteristics which later influences their purchase decision (Suki and Salleh, 2016). Literature proves that there is a higher likelihood of remaining loyal with a particular company, products and services when consumers have positive perception towards it (Nguyen and Leblanc, 2001). Similarly, permissibility in Islam, based on halal and haram, is highly taken into account by Muslim consumers due to the reason that Islamic values have profound influence on the social etiquette of Muslim societies as well as their consumption patterns (Khraim, 2010). It has been found that Muslim consumers hold a deep desire for assuring their purchasing habits parallel with halal image and avoiding non-halal image (Suki and Salleh 2016). Suki and Salleh (2016) described that halal image is favorably associated with Muslims' intention of patronizing to halal stores. Based on such finding the following hypothesis is derived: 
MUSLIM CONSUMERS' PURCHASE BEHAVIOUR TOWARDS SHARIAH COMPLIANT

HOTELS IN MALAYSIA

Hypothesis 1: Halal image has a positive effect on purchase intention towards Shariah compliant hotels.

\section{Halal Awareness and Purchase Intention}

Awareness generally indicates an individual's knowledge along with understanding about a particular issue (Awan et al., 2015). Azam (2016) explicated that in case of halal, the aspect of awareness illustrates individuals' special interest, experience or knowledge regarding the purchase of a product or service. Therefore, Muslim consumers should profoundly aware on the various aspects such as ingredients, process of production, storage as well as other sources and elements that are related to it when purchasing a product (Said and Hassan, 2014). As a result of greater awareness and knowledge regarding halal and haram among Muslim consumers, marketers are no longer able get away from "halalness" issue by just adding a halal logo to the package (Said et al., 2014). Halal awareness has emerged as a crucial issue in the decision-making process of Muslim consumers, specifically in Muslim dominated nations such as Malaysia (Teng and Jusoh, 2013). Yunus et al., (2015) have further shown that halal awareness is crucial for Muslim consumers in the event of buying halal packaged foods produced by non-Muslim companies. Ghadikolaei (2016) also unveiled that halal awareness shares a meaningful association with Muslim consumers' purchase intention. Accordingly, the following hypothesis is derived:

Hypothesis 2: Halal awareness has a positive effect on purchase intention towards Shariah compliant hotels.

\section{Religiosity and Purchase Intention}

Religiosity indicates the extent to which an individual is dedicated to his or her religion (Ramly et al., 2008). According to Salman and Siddiqui (2011) and Mukhtar and Butt (2012) religious commitment has been found to be a primary driver of both Muslim as well as non-Muslims consumers' attitude, behavior, lifestyle as well as consumption habits. They further indicated that adherence to religious principles assists consumers to make sound decisions in life. Thus, consumers' religious beliefs and values occupy a significant part in consumer behavior (Sun et al., 2012). Rehman and Shabbir (2010) indicated that religion is a meaningful aspect that assists individuals in terms of making a distinction between permissible and non-permissible products. Consumers' behavior along with their attitude in terms of their choice, purchase and consumption habit of products largely rely on the degree to which they are devoted to their respective 
religion (Khraim, 2010). Previous research endeavors uncovered that Muslim consumers' religiosity is integral to the formation of their intention to purchase (Jamal and Sharifuddin, 2015; Borzooei and Asgari, 2013). Shaari and Arifin (2009) similarly confirmed that Muslim consumers' purchase intention and religious values are having significant relationships. Said et al., (2015) also found that religiosity of Muslim consumers is meaningfully associated with their consumption. Based on the aforementioned discussion, the following hypothesis is proposed:

Hypothesis 3: Religiosity has a positive effect on purchase intention towards Shariah compliant hotels.

\section{Purchase Intention and Purchase Behavior}

In the field of disciplined inquiry, consumer behavior has substantially evolved over the years in understanding how consumers behave, and now it has become an integral for businesses to sustain in today's intensely competitive environment (Rahman et al., 2012). Purchase behavior is described as consumers' power of making decision when purchase products or services (Rani, 2014). It is vital for marketers to understand the various aspects that lead to the formation of purchase behavior of their target markets and develop strategies accordingly (Khaniwale, 2015). Purchase intention is considered to be a key antecedent that shapes consumers purchase behavior (Nguyen et al., 2010). Researchers have asserted that one of the most effective ways for understanding the actual purchase behavior of consumers is through examining what affects their intentions (Ghalandari and Norouzi, 2012). Intention is one of the major factors that motivate consumers towards making a purchase and ultimately effects their end behavior (Ajzen, 1991). The likelihood that a particular product or service will be purchased by a consumer largely depends of the strength of their willingness of buying that product or service (Hanzaee and Khosrozadeh, 2011). Studies have shown the presence of a favorable association between consumers' intention and their actual purchase behavior (Kim and Pysarchik, 2000). Khairi et al. (2012) found that consumers' purchase behavior shares a strong association with purchase intention. Tarkiainen and Sundqvist (2005) also evidenced that individuals' purchase intention is a significant precursor of their purchase behavior. On the basis of such findings it is hypothesized that: 


\section{MUSLIM CONSUMERS' PURCHASE BEHAVIOUR TOWARDS SHARIAH COMPLIANT HOTELS IN MALAYSIA}

Hypothesis 4: Purchase intention has a positive effect on purchase behavior towards Shariah compliant hotels.

Based on the above literature, the study develops the conceptual framework emphasizing Muslim consumers purchase behavior towards Shariah compliant hotels as illustrated in Figure 1.

Figure 1: Conceptual Framework

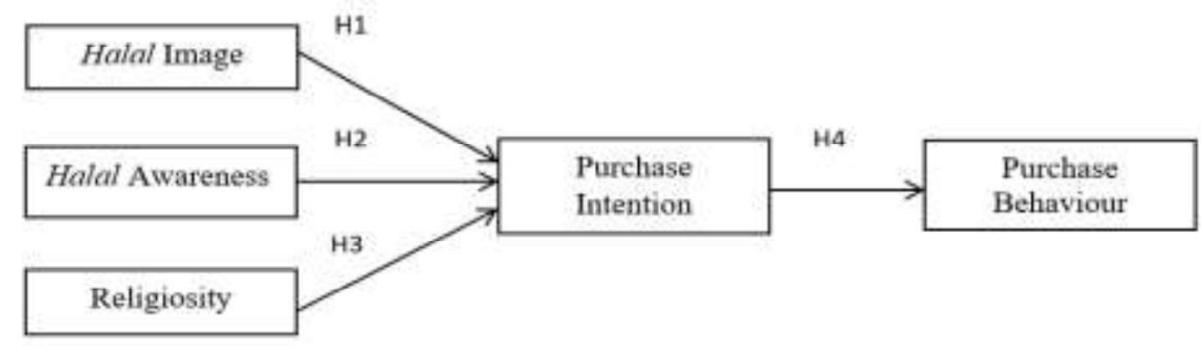

\section{Methodology}

The study adopts a quantitative research method to examine the effects of halal image, halal awareness and religiosity among Muslim consumers on their purchase intention and behavior of Shariah compliant hotels in Malaysia. Therefore, the target population of the study includes Muslim consumers at different tourist places particularly in Kuala Lumpur, Malaysia. The major reason for choosing Kuala Lumpur lies in the fact that it consists of majority of the tourist destinations in the nation. Random sampling method was used to select the sample since it provides an accurate representation of the whole population through ensuring randomness and preventing researcher's bias (Hair et al., 2009). Data were gathered from 426 participants through a selfadministered questionnaire. 5-point Likert scale was used as the measurement of scale where 1 represented strongly disagree and 5 denoted strongly agree. Additionally, operationalization of variables is a vital process for transforming abstract concepts into measurable variables. Halal image was operationalized through consumers' perception regarding Shariah compliant hotels (Awan et al., 2015; Yunus et al., 2015) and Halal awareness through consumers' knowledge and familiarity with Shariah compliant hotels (Awan et al., 2015; Azam, 2016). Religiosity was operationalized as consumers' commitment towards their 
religion along with religious beliefs and values (Rehman and Shabbir, 2010). Purchase intention denotes consumers' willingness to purchase Shariah compliant hotels, and purchase behavior represents consumers' ultimate decision to purchase Shariah compliant hotels (Rani, 2014). Table 1depicts the sources from where the items have been adapted. Statistical Package for Social Science (SPSS) and Structural Equation Modeling (SEM) were employed for analyzing the data.

Table 1: Questionnaire Items

\begin{tabular}{ll}
\hline \multicolumn{1}{c}{ Variable } & \multicolumn{1}{c}{ Source } \\
\hline Halal awareness & Azam (2016) \\
Halal image & Yunus et al. (2015);Awan et al., (2015) \\
Religiosity & Rehman and Shabbir (2010) \\
Purchase Intention & Haque et al., (2015); Lada et al. (2009) \\
Purchase Behavior & Joey (2004) \\
\hline
\end{tabular}

\section{Results and Discussion}

Hair et al. (2009) stated the importance of conducting factor analysis to reduce substantial number of variables into more manageable amount before using them for further analysis. At the same time, factor analysis allows researchers to explore the data set as well as examine the interrelations that takes place among a set of variables (Costello and Osborne, 2005). However, before doing factor analysis it is highly important to run two tests known as Kaiser-Meyer-Olkin (KMO) and Bartlett's Test of Sphericity (Pallant, 2010). As depicted in the Table 2, outcomes of both these tests were within an acceptable level.

Table 2: Kaiser-Meyer-Olkin (KMO)\& Bartlett's test

\begin{tabular}{llr}
\hline Kaiser-Meyer-Olkin Measure of Sampling Adequacy. & .764 \\
\hline \multirow{3}{*}{ Bartlett's Test of Sphericity } & Approx. Chi-Square & 5421.742 \\
& Df & \\
& Sig. & .000 \\
\hline
\end{tabular}

It is very important to ensure that the scales used in the questionnaire are reliable. That refers to the degree to which the items that make up the scale are consistent with each other which means all the measuring express the same underlying construct. The reliability of the items in the questionnaire was investigated with Cronbach's Alpha, which the value ideally should be above 7 (Pallant, 2010). 


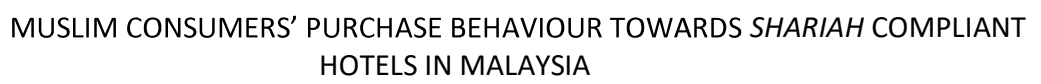

Table 3. Reliability of the Data

\begin{tabular}{lcc}
\hline Component & Cronbach's Alpha & No. of items \\
\hline Halal Image & .826 & 5 \\
Halal Awareness & .859 & 5 \\
Religiosity & .801 & 5 \\
Purchase Intention & .844 & 5 \\
Purchase Behavior & .762 & 5 \\
\hline
\end{tabular}

Table 4 shows the rotated component matrix, a total of 25 items were generated whereby, all the items can be considered significant since they managed to load with a value more than 0.50 (Hair et al., 2009).

Table 4: Rotated Component Matrix

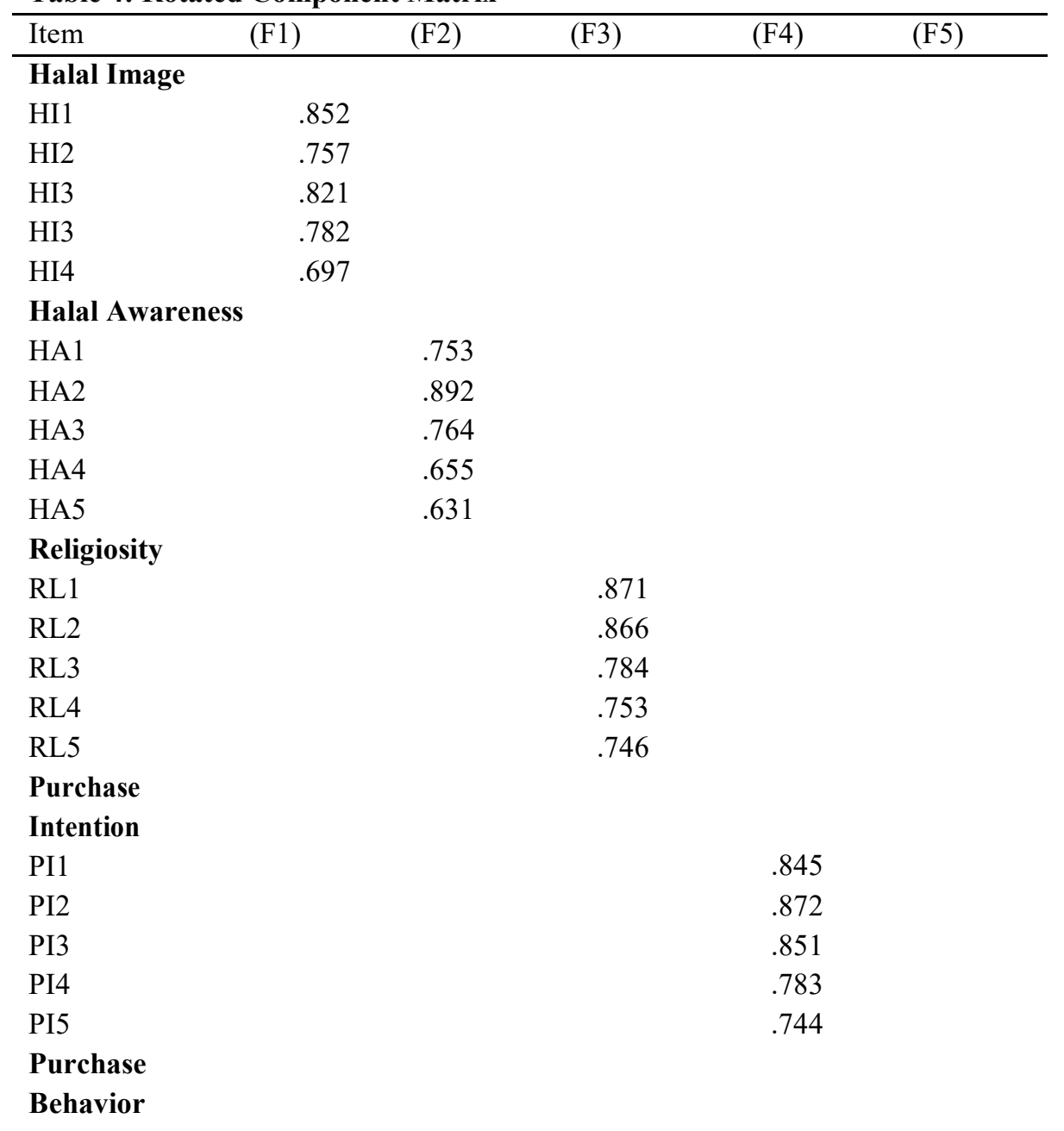


Extraction Method: Principal Component Analysis

\section{Evaluation of the Structural Model}

Structural Equation Modeling (SEM) was performed to verify the fitness adequacy of the model. To evaluate the model fit a number of fit indices were used such as Normed Chi-square, CFI, GFI and RMSEA as they are highly recommended in literature (Zainudin, 2012). As recommended by Hair et al. (2010) items loaded with a value lower than the threshold value of 0.50 were removed and the model was re-specified. Accordingly, as shown in Figure 2 and Table 5, the final model consists with Root Mean Square Error Approximation $(\mathrm{RMSEA})=.067,(\mathrm{CFI})=.913,(\mathrm{GFI})=.913$, and Normed $\chi 2=2.034$.

Figure 2: Structural Model of Purchase Behavior towards Shariah Compliant Hotel

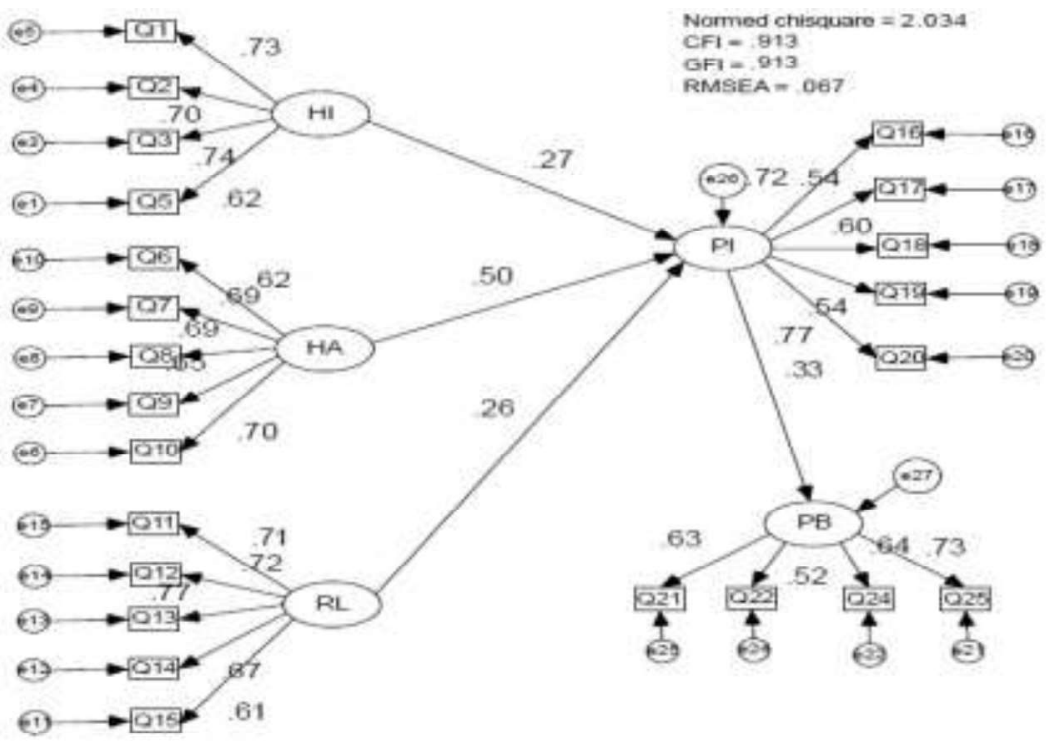


MUSLIM CONSUMERS' PURCHASE BEHAVIOUR TOWARDS SHARIAH COMPLIANT HOTELS IN MALAYSIA

Table 5: Fitness Assessment of the Structural Model

\begin{tabular}{|c|c|c|c|}
\hline $\begin{array}{l}\text { Name of } \\
\text { category }\end{array}$ & $\begin{array}{l}\text { Required } \\
\text { value }\end{array}$ & $\begin{array}{l}\text { Obtained } \\
\text { Value }\end{array}$ & Comments \\
\hline Absolute fit & $\begin{array}{l}\text { RMSEA }^{* *} \leq \\
0.08 \\
\text { GFI }^{* *} \geq 0.90\end{array}$ & $\begin{array}{l}0.067 \\
0.913\end{array}$ & $\begin{array}{l}\text { The required value is } \\
\text { attained }\end{array}$ \\
\hline Incremental fit & $\mathrm{CFI} I^{* *} \geq 0.90$ & 0.913 & $\begin{array}{l}\text { The required value is } \\
\text { attained }\end{array}$ \\
\hline Parsimonious fit & $\chi 2 / \mathrm{df}^{* *} \leq 3$ & 2.034 & $\begin{array}{l}\text { The required value is } \\
\text { attained }\end{array}$ \\
\hline
\end{tabular}

Source. Byrne (2010); Hair et al. (2010); Kline (2011); Zainudin (2012).

Note. ${ }^{*}$ These indices are recommended since these are highly reported in the literature RMSEA

$=$ root mean square error approximation; $\mathrm{GFI}=$ goodness-of-fit index; $\mathrm{CFI}=$ comparative fit index; Chisq/df $=$ Chi Square/Degree of Freedom

\section{Hypotheses Testing}

The structural model output was used to test the hypotheses. Table 6 summarizes the hypotheses testing result for the current study.

Table 6: Result of Hypotheses Testing

\begin{tabular}{|c|c|c|c|c|c|c|c|c|}
\hline Hypotheses & Reg & $\begin{array}{l}\text { darc } \\
\text { ion }\end{array}$ & $\begin{array}{l}\text { zed } \\
\text { Jeights }\end{array}$ & Estimate & S.E. & C.R. & $\mathrm{P}$ & Outcome \\
\hline H1 & PI & $<-$ & HI & .258 & .054 & 5.721 & $* * *$ & Accepted \\
\hline $\mathrm{H} 2$ & PI & $<-$ & HA & .205 & .045 & 3.168 & $* * *$ & Accepted \\
\hline $\mathrm{H} 3$ & PI & $<-$ & $\mathrm{RL}$ & .047 & .076 & 3.862 & .003 & Accepted \\
\hline $\mathrm{H} 4$ & PB & $<--$ & PI & .086 & .033 & 2.667 & .004 & Accepted \\
\hline
\end{tabular}

According to the findings, aspects of halal image, halal awareness as well as religiosity play integral role in Muslim consumers' purchase intention towards Shariah compliant hotels. The outcomes derived from the present study were supported by the literature. Halal image is considered to be one of the primary antecedents of Muslim consumers purchase intention (Lada et al., 2009). A favorable relation between halal image and purchase intention was previously disclosed by Suki and Salleh (2016) whereby they have found that halal image significantly affected the purchase intention of Muslim consumers. In the past a number of studies were undertaken for investigating the effect of halal awareness on the buying behavior of Muslim consumers (Azam, 2016; Said et al., 2014; Teng and Jusoh, 2013). The outcomes of these studies have revealed a meaningful association between these two factors. Similarly, Ghadikolaei, (2016) and Yunus et al., (2015) found a relationship between halal awareness and purchase intention. Religiosity is an integral factor that affects consumers' choice of products/services (Mukhtar and Butt, 2012; Salman and 
Siddiqui, 2011; Rehman and Shabbir, 2010). Jamal and Sharifuddin (2015), Said et al. (2014) and Borzooei and Asgari (2013) also proved the effect of religiosity of Muslims on their purchase intention. Khairi et al. (2012) and Tarkiainen and Sundqvist, (2005) have established that consumers' purchase behavior largely relies on their purchase intention.

\section{Conclusion and Recommendations}

The present study attempted to investigate the aspects are vital for gaining an understanding regarding Muslim consumers purchase behavior towards Shariah compliant hotels. In line with the findings derived from the study it is recommended that destination marketers should take the initiative of enhancing the halal image of Shariah compliant hotels through building positive perception in the minds of the consumers. Additionally, marketers should enhance consumers' awareness regarding the halal aspect of Shariah compliant hotels through various marketing activities. Consequently, the findings have also shown that Muslim consumers religiosity affects their purchase intention towards Shairah compliant hotels. To encourage Muslim consumers to visit Shariah compliant hotels, marketing strategies and activities should be developed in accordance to Islamic principles by avoiding anything that may offend the religious beliefs of Muslim consumers. Finally, marketers of Shariah compliant hotels should try their best to create a positive intention among Muslim consumers. This is because the existence of positive intention will lead to positive purchase behavior toward Shariah compliant hotels.

Even though the present research contributes to the literature of purchase behavior towards Shariah compliant hotels, it has some limitations. The first limitation is in terms of the study's location. Data for the research at hand was gathered only from the tourist destinations in Kuala Lumpur, it may in turn influence the generalizability of the outcomes. Henceforth, it's great for future studies if they gather data from a larger number of tourist places to obtain a more comprehensive representation of the population. Moreover, it is also advised that the conceptual model of this study can be further developed in the future including new mediating as well as moderating variables. Finally, the model of the study can be tested in the setting of different countries as well as industries. 
MUSLIM CONSUMERS' PURCHASE BEHAVIOUR TOWARDS SHARIAH COMPLIANT
HOTELS IN MALAYSIA

\section{References}

Ajzen, I. (1991). The theory of planned behaviour. Organizational behaviour and human decision processes, Vol50(2), 179-211.

Awan, H.M., Siddiquei, A.N. and Haider, Z. (2015). Factors affecting Halal purchase intention-evidence from Pakistan's Halal food sector. Management Research Review, Vol 38 (6), 640-660.

Azam, A. (2016). An empirical study on non-Muslim's packaged Halal food manufacturers: Saudi Arabian consumers' purchase intention. Journal of Islamic Marketing, Vol 7(4), 441-460.

Battour, M., Ismail, M.N. and Battor, M. (2011), "The impact of destination attributes on Muslim tourist's choice". International Journal of tourism research, Vol. 13, No. 6, pp. 527-540.

Borzooei, M. and Asgari, M. (2013). The Halal brand personality and its effect on purchase intention. Interdisciplinary Journal of Contemporary Research in Business, Vol 5(3), 481-491.

Byrne, B.M. (2010). Structural equation modelling with AMOS: Basic concepts, applications, and programming. Taylor and Francis Group, New York.

Costello, A.B. and Osborne, J.W. (2005), Best practices in exploratory factor analysis: Four recommendations for getting the most from your analysis. Practical assessment, research and evaluation, Vol 10(7), 1-9.

Deuraseh, N. (2009). Lawful and unlawful foods in Islamic law focus on Islamic medical and ethical aspects. International Food Research Journal, Vol 16, 469-478.

Ghadikolaei, F.S. (2016). The effect of halal signs and symptoms on consumers' purchase intention in Muslim and non-Muslim countries - A review. International Journal of Business and Management Invention, Vol 5(7), 44-49.

Ghalandari, K.\&Norouzi, A. (2012). The Effect of Country of Origin on Purchase Intention: The role of product knowledge. Research Journal of Applied Sciences, Engineering and Technology, Vol 4(9), 1166-1171. 
Hair, J.F., Black, W.C., Babin, B.J., \& Anderson, R.E. (2010). Multivariate Data Analysis (7th edn.). New Jersey: Pearson Prentice Hall.

Hair, J.F., Bush, R.P., and Ortinau, D.J. (2009). Marketing research: in a digital information environment, McGraw-Hill/Irwin, New York.

Hanzaee, K.H., and Khosrozadeh, S. (2011). The effect of the country-of-origin image, product knowledge and product involvement on information search and purchase intention. Middle-East Journal of Scientific Research, Vol 8(3), 625-636.

Haque, A., Sarwar, A., Yasmin, F., Tarofder, A.K. and Hossain, M.A. (2015). Non-Muslim consumers' perception toward purchasing halal food products in Malaysia. Journal of Islamic Marketing, Vol 6(1), 133-147.

Henderson, J.C. (2010). Sharia-compliant hotels. Tourism and Hospitality Research, 10(3), 246-254.

Henderson, J.C. (2003), Managing tourism and Islam in peninsular Malaysia. Tourism management, Vol 24(4), 447-456.

Idris, J.\& Razali, A.R. (2016). A study of consumer behaviour towards Islamic hotel: assessing on knowledge and religiosity. In 2nd International Conference on Economics \& Banking.

Jamal, A. and Sharifuddin, J. (2015). Perceived value and perceived usefulness of Halal labeling: The role of religion and culture. Journal of Business Research, Vol 68(5), 933-941.

Joey, F. \& George, J.F. (2004). The theory of planned behavior and Internet purchasing. Internet Research, Vol 14(3), 198-212.

Kandampully, J.\& Suhartanto, D. (2000). Customer loyalty in the hotel industry: the role of customer satisfaction and image. International journal of contemporary hospitality management, 12(6), 346-351. 
Khairi, M.O., Nik Mat, N.K., Imhemed, G.A., \& Ahamed Ali, F.M. (2012). The direct effects of Halal product actual purchase antecedents among the international Muslim consumers. American Journal of Economics, Vol 2(1), 87-92.

Khaniwale, M. (2015). Consumer buying behavior. International Journal of Innovation and Scientific Research, Vol 14(2), 278-286.

Khraim, H. (2010). Measuring religiosity in consumer research from an Islamic perspective. Journal of Economic and Administrative Sciences, Vol 26(1), 52-78.

Kim, S. \& Pysarchik, D.T. (2000). Predicting purchase intentions for uninational and bi-national products. International Journal of Retail \& Distribution Management, Vol28(6), 280-291.

Kline, R.B. (2011). Principals and Practice of Structural Equation Modeling, (3rd edn.). New York: Guilford.

Lada, S., Harvey Tanakinjal, G. and Amin, H. (2009). Predicting intention to choose Halal products using theory of reasoned action. International Journal of Islamic and Middle Eastern Finance and Management, Vol 2(1), 66-76.

Mukhtar, A. and Mohsin Butt, M. (2012). Intention to choose Halal products: the role of religiosity. Journal of Islamic Marketing, Vol3(2), 108-120.

Nguyen, N. and Leblanc, G. (2001). Corporate image and corporate reputation in customers' retention decisions in services. Journal of retailing and Consumer Services, Vol 8(4), 227-236.

Nguyen, T.D., Nguyen, T., \& Barrett, N.J. (2010). Consumer ethnocentrism, cultural sensitivity, and intention to purchase local products evidence from Vietnam. Journal of consumer behaviour, Vol7(1), 88-100.

Pallant, J. (2010). SPSS survival manual: A step by step guide to data analysis using SPSS, Open University Press, Berkshire. 
Rahman, M.S., Haque, M.M., \& Khan, A.H. (2012). A conceptual study on consumers' purchase intention of broadband services: Service quality and experience economy perspective. International Journal of Business and Management, Vol7(18), 115-129.

Ramly, Z., Chai, L.T. and Lum, C.K. (2008). Religiosity as a predictor of consumer ethical behavior: Some evidence from young consumers from Malaysia. Journal of Business Systems, Governance and Ethics, Vol $3(4), 43-56$.

Rani, P. (2014). Factors influencing consumer behavior. International Journal of Current Research and Academic Review, Vol 2(9), 52-61.

Rehman, A.U. and Shabbir, S.M. (2010). The relationship between religiosity and new product adoption. Journal of Islamic Marketing, Vol 1(1), 6369.

Rishipal. (2014). Customer Loyalty towards Hotel Industry in India. International Journal of Science and Research, 3(12), 1362-1365.

Rosenberg, P.\& Choufany, H.M. (2009). Spiritual lodging-The Shariacompliant hotel concept. HVS Global Hospitality Services, Dubai.

Saad, H.E., Badran, N.\& Abdel-Aleem, M. (2016). Sharia-compliant hotels in Egypt: Concept and challenges. Journal of Faculty of Tourism and Hotels, Fayoum University, 7(2), 1-12.

Said, M., Hassan, F., Musa, R. and Rahman, N.A. (2014), Assessing Consumers' Perception, Knowledge and Religiosity on Malaysia's Halal Food Products. Procedia-Social and Behavioral Sciences, Vol 130, 120128.

Salleh, N. Z. M., Hamid, A. B. A., Hashim, N. H., \& Omain, S. Z. (2014). The Practice of Shariah-Compliant Hotel in Malaysia. International Journal of Trade, Economics and Finance, 5(1), 26-37.

Salman, F. and Siddiqui, K. (2011). An exploratory study for measuring consumer awareness and perceptions towards Halal food in Pakistan. 


\section{MUSLIM CONSUMERS' PURCHASE BEHAVIOUR TOWARDS SHARIAH COMPLIANT HOTELS IN MALAYSIA}

Interdisciplinary Journal of Contemporary Research in Business, Vol 3(2), 639-652.

Samori, Z. \& Rahman, F.A. (2013). Towards the formation of Shariah complaint hotel in Malaysia: An exploratory study on its opportunities and challenges. In WEI International Academic Conference Proceedings, Istanbul, Turkey.

Shaari, J.A.N., and Arifin, M.N.S. (2009). Dimension of Halal purchase intention: A preliminary study. In American Business Research Conference, New York, USA, 1-15.

Suki, N.M. and Salleh, A.S.A. (2016). Does Halal image strengthen consumer intention to patronize Halal stores. Journal of Islamic Marketing, Vol $7(1), 120-132$.

Sun, S., Goh, T., Fam, K.S., Xue, Y. and Xue, Y. (2012), The influence of religion on Islamic mobile phone banking services adoption. Journal of Islamic Marketing, Vol 3(1), 81-98.

Tabachnick, B.G., Fidell, L.S., and Osterlind, S.J. (2001). Using multivariate statistics. Allyn and Bacon, Massachusetts.

Tarkiainen, A. and Sundqvist, S. (2005). Subjective norms, attitudes and intentions of Finnish consumers in buying organic food. British food journal, Vol107(11), 808-822.

Teng, P. K., and Jusoh, W. J. (2013). Investigating student awareness and usage intention towards Halal labelled cosmetics and personal care products in Malaysia. In 4th International Conference on Business and Economic Research (4th ICBER 2013), Indonesia: Bandung.

Xuan, N.T.T. (2017). A Review of Customer Loyalty Models in Hotel Services and Research Model in Vietnam. Global Review of Research in Tourism, Hospitality and Leisure Management, 3(1), 453-463. 
Yunus, M.N.S.N., Abd-Razak, N., \& Ghani, N.M.A. (2014). Consumer purchase intention towards Sharia Compliant Hotel ( $\mathrm{SCH})$. Theory and Practice in Hospitality and Tourism Research, 155-167.

Yunus, N.S.N.M., Rashid, W.E.W., Ariffin, N.M., and Rashid, N.M. (2015). Muslim's Purchase Intention towards Non-Muslim's Halal Packaged Food Manufacturer. Procedia-Social and Behavioral Sciences, Vol 130, 145-154.

Zainudin, A. (2012). A handbook on SEM: Structural equation modelling. University Technology MARA, Kelantan.

Zamani-Farahani, H., and Henderson, J.C. (2010). Islamic tourism and managing tourism development in Islamic societies: the cases of Iran and Saudi Arabia. International journal of tourism research, Vol 12(1), 79-89. 